\title{
平滑な接合面における鉄筋の せん断伝達に関する研究
}

\author{
篠田佳男 ${ }^{1} \cdot$ 河野一徳 $^{2} \cdot$ 田中伯明 ${ }^{3} \cdot$ 大野环海 $^{3}$ \\ ${ }^{1}$ 正会員 前田建設工業株式会社 技術研究所( \\ 2 正会員工修 前田建設工業株式会社 技術研究所( 179 東京都練馬区旭町1-39-16) \\ ${ }^{3}$ 前田建設工業株式会社 土木設計部（テ179 東京都練馬区高松5-8 J. CITY)
}

\begin{abstract}
本研究は平滑なコンクリート接合面におけるせん断伝達のメカニズムとして，鉄筋のダウエル作用に着 目して検討を行った。実験はPush-off型一面せん断試験体を使用し，D25やD32と比較的太径の鉄筋につい てせん断伝達メカニズムを把握するために行った．その結果，せん断力は平滑な接合面を貫通する鉄筋の 曲げにより，接合面から鉄筋径の 5 倍以内と局部的な領域で抵抗することが明らかとなったささらに，鉄 笳の全塑性状態に着目した降伏せん断強度式を提案し，その妥当性を示した。
\end{abstract}

Key Words : construction joint, shear transfer, dowel action, reinforced concrete

\section{1.はじめに}

昨今の地下空間の高度利用という社会的な要請か ら，地中連続壁の本体利用が進められ，その適用も 大型化・地下深層化へと向かっている.また，コン クリート工事の合理化の推進から，土木分野におい てもプレキャスト工法の開発・実用化が図られてい る.これらの工法・構造において，壁体間や部材間 には新旧コンクリートの接合面が存在し，コンクリ 一ト部材間の接合技術が設計・施工面から重要な検 討課題となっている.

従来, この種の接合面は構造的に弱点とみなされ, できるだけせん断力の小さい位置に設ける，あるい はその方向を部材の圧縮力の作用方向と直角にする のを原則とする ${ }^{1}$ 等の制限が加えられている. また， 設計上も，設計耐力を小さくして検討されているの が実情である．特に，その接合面が平滑な面の場合 には，その継ぎ目位置がさらに制限されることとな っている.

平滑な面入作用するせん断力は，その面を貫通す る鉄筋によるせん断伝達，いわゆる鉄筋のダウエル 作用により伝達される. 鉄筋のダウエル作用は従来 より研究がなされ, 既往の研究に示すように研究成 果が蓄積されてきている. 特に, 最近では軸方向鉄 筋の挙動に関する検討が進められ, 軸引張力の影響 を含め, 軸方向鉄筋の抵抗メカニズムが明らかとさ れてきている2〉，3)，4).

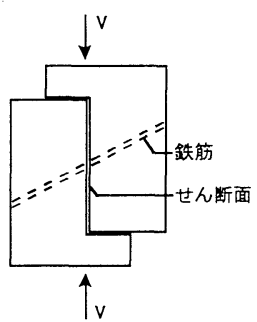

(a) Push-off試験

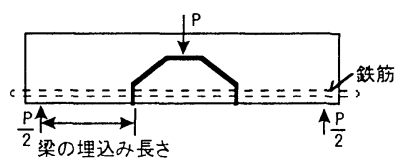

(b) 分離された梁試験

図-1 鉄筋のダウエル作用に関する実験

本研究は，D25やD 32といった比較的太径の鉄筋 を対象に，平滑な接合面における鉄筋のダウエル作 用によるせん断伝達メカニズムの把握を主な目的と して行ったものである. また，鉄筋の抵抗メカニズ ムを考慮したせん断強度について検討を加えた。

\section{2. 既往の研究}

鉄筋のダウエル作用に関する研究は，図-1に示す ように, Push-off試験に代表される直接せん断実験 と，梁を使用した実験に分けられる. 

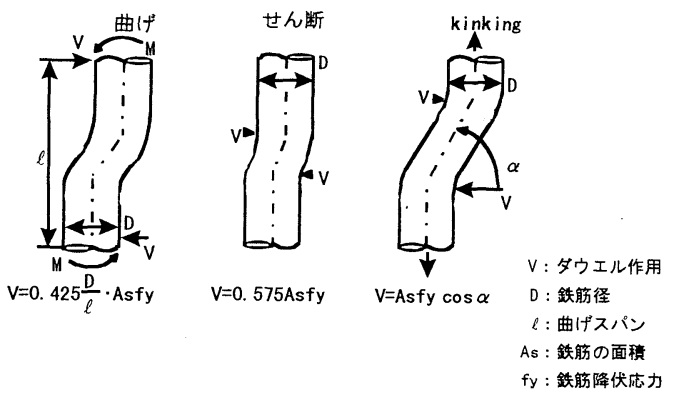

図-2 ダウエル作用の $3 つ の$ 形態

Pauleyらは，ダウエル作用における荷重伝達の可 能な形態を図-2に示すような 3 種類に分類した ${ }^{5)}$.

(1) 鉄筋の曲げ; 長さとの鉄筋の両端に生じる曲 げモーメントMにより抵抗する.

(2) 鉄筋のせん断 : コンクリートの局部支圧が十 分である場合に純せん断で抵抗する.

(3) Kinking; 鉄筋軸のズレが生じ, 鉄筋軸力の分 力がせん断力に抵抗する.

これらの形態から，鉄筋の曲げに支配されれば， せん断耐力は鉄筋径の 3 乗に比例し, 鉄筋のせん断 とKinkingが支配的ならば，鉄筋径の 2 乗に比例す ることとなる.

KrefeldとThurston, Taylor, および Houde は, 分離された梁の試験結果に基づき，ダウエル作用に よる終局耐力はかぶりや梁幅が増すに従い，值を大 きくすることを確認し，また表-1に示すように算定 式を提案している6)，7)，8).

Dulacskaは，せん断面を貫通する鉄筋の曲げを重 視したモデル化を行い，これを解析し，耐力評価式 を提案している ${ }^{9)}$.

山田らは，せん断面を貫通する鉄筋の角度および 鉄筋比をパラメータとして，ひび割れ面でのせん断 伝達におけるダウエル作用の影響度合いを直接せん 断実験により検討した ${ }^{10)}$. その結果, ダウエル作 用は，貫通する鉄筋がひび割れ面と直交するときに 最大となり, また鉄筋比が大きいほど, せん断伝達 に占めるダウエル作用の分担率が大きくなるとして いる.

また，鉄筋のダウエル作用に与える軸引張力の影 響についても検討が進められている2)，3)，4). 前川 らは，コンクリート中の鉄筋に引き抜けと軸直交変 位を与え, 軸直交変位により引き抜け耐力が一軸の 引き抜け耐力に比べ低下することを実験的に確認し た。また，軸直交変位により鉄筋に曲率が生じ，曲 率の影響領域はひび割れ面から鉄筋径の $5 \sim 6$ 倍ま で存在することを示した．さらに，鉄筋を梁モデル
表-1 鉄筋のダウエル作用に関する算定式

\begin{tabular}{|c|c|}
\hline 提 案 者 & 式 \\
\hline $\begin{array}{l}\text { Krefeld と } \\
\text { Thurston } \\
\qquad \text { (梁試験) }\end{array}$ & 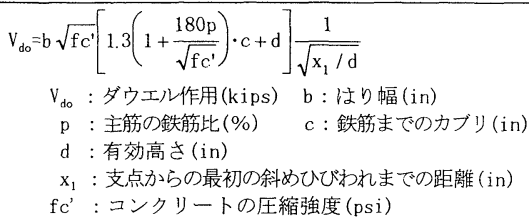 \\
\hline Taylor & $\begin{aligned} & \mathrm{V}_{\mathrm{do}}=2.04+0.1 \mathrm{bn}^{2} \mathrm{ft}^{\prime} \\
& \mathrm{V}_{\mathrm{do}}: \text { : ダウエル作用 }(\mathrm{kips}) \quad \text { bn : 純はり幅 }(\mathrm{in}) \\
& \mathrm{ft} \mathrm{t}^{\prime}: \text { : コンクリートの引張強度 }(\mathrm{ksi})\end{aligned}$ \\
\hline Houde & $\begin{aligned} V_{\mathrm{do}}=0.040 \mathrm{bn}^{3} \sqrt{\mathrm{fc}^{\prime}} & \\
V_{\mathrm{do}} & : \text { ダウエル作用 }(\mathrm{kips}) \quad \mathrm{bn}: \text { 純はり幅 }(\mathrm{in}) \\
\mathrm{f}^{\prime} \mathrm{c} & : \text { ユンクリートの圧縮強度 }(\mathrm{psi})\end{aligned}$ \\
\hline Dulacska & $\begin{aligned} \mathrm{T}_{\mathrm{f}}=0.2 \phi^{2} \sigma \mathrm{ysin} \delta\left[\sqrt{1+\frac{\sigma \mathrm{c}}{\sqrt{0.03 \sigma \operatorname{ysin}^{2} \delta}}}-1\right] \\
\mathrm{T}_{\mathrm{f}} \quad: \text { 最大荷重 } \\
\phi \quad: \text { 鉄筋径 } \\
\sigma \mathrm{y}: \text { 鉄筋の降伏応力 } \\
\delta \quad: \text { せん断補強筋のせん断面となす角 } \\
\sigma c: \text { コンクリート縮強度 }\end{aligned}$ \\
\hline
\end{tabular}

を修正したモデルに置き換えて検討を行い，その抵 抗機構を説明した.

さらに, Gambarovaらは, 鉄筋に軸直交変位を与 え, ダウエル作用のメカニズムについて実験的検討 を行った ${ }^{11)}$. その結果, 鉄筋が弾性挙動を呈する のは最大荷重の $40 \%$ 以下であること, 最大荷重の 60 \%に達するとせん断面から $1 \mathrm{D}$ 程度離れた位置で鉄 筋断面の $50 \%$ が塑性化し，大きな曲率が生じている ことを明らかにした。 また，軸直交変位および耐力 について検討を加えた.

一方，1980年代以降，わが国において地下空間の 高度利用という観点から, 地中連続壁の本体利用が 脚光を浴び，地中連続壁間の継手を対象に多くの実

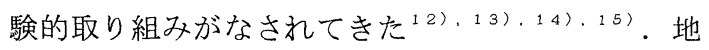
中連続壁間は, 通常平滑な鋼板で仕切られるため, 本体利用を進める場合, 曲げやせん断力を伝達する 構造継手を開発する必要があり, 各種の構造継手が 開発されてきた。また, 地中連続壁は大断面の大型 構造物となることが多く, 鉄筋のダウエル作用に期 待したせん断実験も，太径の鉄筋を使用した大型の 試験体を使用して行われている.

武田らは，壁間を平滑な鋼板で仕切られた接合面 において，図-3に示す鉛直継手を考案した。これは 継手を構成する主筋と, せん断補強を目的に接合面 を貫通して配置した鉄筋（以下シア筋と称す）から なる. この接合面での終局せん断強度は, 主筋とシ ア筋による鉄筋比と鉄筋の降伏応力との積 $\mathrm{p} \cdot \mathrm{fy}$ の一 次関数を用いたせん断摩擦理論 ${ }^{16)}$ に準じて評価さ れている. 
表-2 Aシリーズ試験一覧

\begin{tabular}{|c|c|c|c|c|c|c|c|c|}
\hline \multirow{2}{*}{\multicolumn{2}{|c|}{ 試 験 体 }} & \multirow{3}{*}{$\begin{array}{l}\text { 接合面 } \\
\text { コンクリート面 }\end{array}$} & \multirow{3}{*}{$\frac{\text { 鉄筋径 }}{}$} & \multirow{3}{*}{$\begin{array}{l}\text { 本 数 } \\
\text { (本) } \\
6\end{array}$} & \multirow{3}{*}{$\begin{array}{c}\text { 鉄筋比 } \\
(\%) \\
1.41\end{array}$} & \multicolumn{2}{|c|}{$\begin{array}{c}\text { コンクリートの圧縮強度 } \\
\left(\mathrm{kgf} / \mathrm{cm}^{2}\right)\end{array}$} & \multirow{3}{*}{$\begin{array}{c}\begin{array}{c}\text { 降伏せん断強度 } \\
\left(\mathrm{kgf} / \mathrm{cm}^{2}\right)\end{array} \\
19.7\end{array}$} \\
\hline & & & & & & \multirow{2}{*}{\begin{tabular}{|c|} 
先打部分 \\
286 \\
\end{tabular}} & \multirow{2}{*}{\begin{tabular}{|c|} 
後打部分 \\
245 \\
\end{tabular}} & \\
\hline 1 & $\mathrm{D} 25 \mathrm{C}$ & & & & & & & \\
\hline 2 & D25NF & テフロン面 & D25 & 6 & 1.41 & 314 & 318 & 18.1 \\
\hline 3 & $\mathrm{D} 32 \mathrm{C}$ & コンクリート面 & D32 & 4 & 1.47 & 313 & 299 & 20.2 \\
\hline 4 & D32NF & テフロン面 & D32 & 4 & 1.47 & 313 & 320 & 17.1 \\
\hline
\end{tabular}

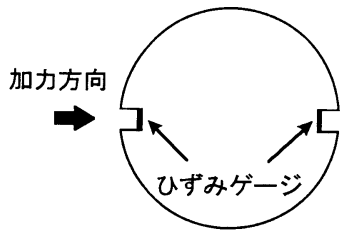

図-4ひずみ測定方法

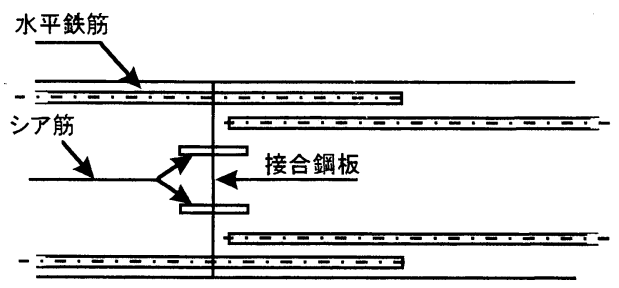

図-3 地中連続壁鉛直継手

表-3 コンクリートの配合

\begin{tabular}{|c|c|c|c|c|c|c|c|}
\hline スランプ & 水セxント & 細骨材 & \multicolumn{5}{|c|}{ 単位量 $\left(\mathrm{kg} / \mathrm{m}^{3}\right)$} \\
\hline$(\mathrm{cm})$ & $(\%)$ & $(\%)$ & 水 & セxント & 細骨材 & 粗骨材 & 混和闵 \\
\hline 18 & 57.5 & 48.7 & 185 & 322 & 857 & 918 & 3. 61 \\
\hline
\end{tabular}
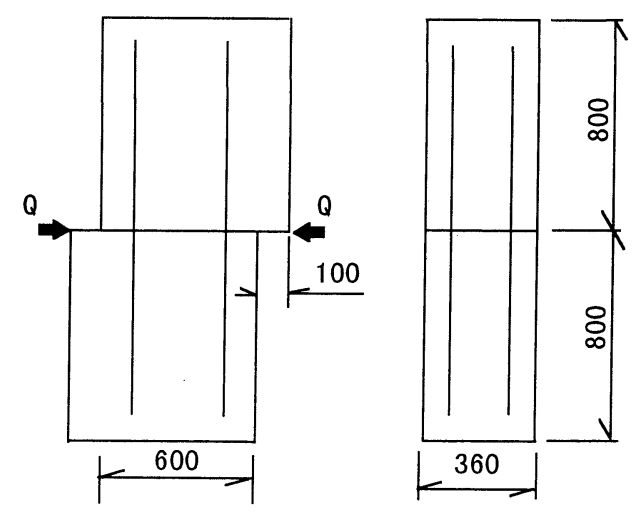

図-5 試験体の形状寸法

表-4 鉄筋の機械的性質

岡田は，接合面を限界状態設計法によって設計す るための設計せん断伝達式として, 接合面の状態が 平滑面から凹凸面までも考慮できる算定式を提案し ている ${ }^{17)}$.

鉄筋のダウエル作用に関する研究は，過去50年以 上にわたつて実施されており，特に最近ではその抵 抗メカニズムについて明らかにされつつある.

\section{3. 実験概要}

実験は，平滑な面におけるせん断伝達を詳細に把 握し,さらに耐荷力の評価を目的に計画した. 試験 体は, Aシリーズ, Bシリーズに分け, 合計19体と した.

Aシリーズは, せん断伝達のメカニズムを詳細に 把握することを主眼としており，先打ち部分の表面 を化粧合板による型枠面として表面の平滑度を確保 した。また，せん断面は，平滑な面を有する先打ち 部分に後打ち部分のコンクリートを直接打設したも のと, 厚さ0.01mmのテフロンシートを 2 枚, その間 にシリコングリスを塗布して配置することにより， コンクリートの摩擦を除去し, 鉄筋のダウエル作用 のみでせん断力を評価するものに分けた.

使用した試験体は，表-2に示す 4 体で, 鉄筋の径 をD25とD32とし，鉄筋比がほぼ同一となるように

\begin{tabular}{|c|c|c|c|}
\hline & $\begin{array}{c}\text { 降伏強度 } \\
\left(\mathrm{kgf} / \mathrm{cm}^{2}\right)\end{array}$ & $\begin{array}{c}\text { 引張強度 } \\
\left(\mathrm{kgf} / \mathrm{cm}^{2}\right)\end{array}$ & $\begin{array}{c}\text { 弾性係数 } \\
\left(\mathrm{kgf} / \mathrm{cm}^{2}\right)\end{array}$ \\
\hline D25 & 4115 & 5990 & $2.04 \times 10^{6}$ \\
\hline D32 & 3786 & 6240 & $2.08 \times 10^{6}$ \\
\hline
\end{tabular}

鉄筋の本数を決定した. 鉄筋は，溝切り加工（幅 ; $3 \mathrm{~mm}$, 深さ; $3 \mathrm{~mm})$ を施した鉄筋を使用し, この位置 にひずみゲージを貼付, 溝の部分でコーティングす ることで，鉄筋の付着性状を乱さないようにした。 ひずみゲージは，図-4に示すように，鉄筋の中心軸 に対して加力側と, その反対側に位置するように配 置し，ずれ変位を伴う鉄筋の曲げひずみと軸ひずみ の両者を検出できるようにした。なお，測定位置は， せん断面から $3 \mathrm{D}$ (D; 鉄筋径) 区間は0.5D間隔と密 にした.

試験体は，図-5に示すように，打継ぎ面が $60 \times 36$ $\mathrm{cm}$ で, 先打ち部分および後打ち部分ともに高さが 80 cmの形状寸法を有するものである. また，試験体一 の載荷は, 載荷方向とせん断面が一致し, せん断面 に直接せん断力が作用するPush-off型一面せん断試 験とした.

コンクリートは表-3に示す配合のものを，また鉄 筋は表-4に示す機械的性質のもので，D25にSD345 を，D32にSD295をそれぞれ使用した。 
表-5Ｂシリーズ試験一覧

\begin{tabular}{|c|c|c|c|c|c|c|c|c|c|}
\hline \multicolumn{3}{|c|}{ 試 験 体 } & \multicolumn{2}{|c|}{ 主 筋 } & \multicolumn{2}{|c|}{ せん断補強 } & \multirow{2}{*}{$\begin{array}{c}\text { 鉄筋比 } \\
(\%)\end{array}$} & \multirow{2}{*}{$\begin{array}{c}\text { コンクリートの圧縮強度 } \\
\left(\mathrm{kgf} / \mathrm{cm}^{2}\right)\end{array}$} & \multirow{2}{*}{$\begin{array}{c}\text { 降伏せん断強度 } \\
\left(\mathrm{kgf} / \mathrm{cm}^{2}\right) \\
\end{array}$} \\
\hline No. & 継手構造 & 名 称 & 鉄筋径 & 本数 (本) & 鉄筋径 & 本数 (本) & & & \\
\hline 1 & \multirow{7}{*}{ 主筋構造 } & SRJ51 & D25 & 6 & - & - & 0.51 & 229 & 8.5 \\
\hline 2 & & SRJ80 & D32 & 6 & - & - & 0.80 & 203 & 12.7 \\
\hline 3 & & SRJ86 & D25 & 10 & - & - & 0.86 & 229 & 11.8 \\
\hline 4 & & SRJ107 & D32 & 8 & - & - & 1.07 & 203 & 16.9 \\
\hline 5 & & SRJ120 & D25 & 14 & - & - & 1.20 & 229 & 20.3 \\
\hline 6 & & SRJ154 & D32 & 10 & - & - & 1.34 & 267 & 20.3 \\
\hline 7 & & SRJ188 & D32 & 14 & - & - & 1. 88 & 203 & 28.9 \\
\hline 8 & \multirow{8}{*}{ 㳄筋椪造 } & SRJ80S4-15 & D32 & 6 & D32 & 4 & 1.34 & 200 & 19.7 \\
\hline 9 & & SRJ80S4-25 & D32 & 6 & D32 & 4 & 1.34 & 200 & 20.1 \\
\hline 10 & & SRJ80S4-40 & D32 & 6 & D32 & 4 & 1.34 & 200 & 20.3 \\
\hline 11 & & SRJ80S2 & D32 & 6 & D32 & 2 & 1.07 & 228 & 17.0 \\
\hline 12 & & SRJ80S6 & D32 & 6 & D32 & 6 & 1.61 & 228 & 25.3 \\
\hline 13 & & SRJ20S4 & D16 & 6 & D32 & 4 & 0.74 & 203 & 11.8 \\
\hline 14 & & SRJ51S4 & $\mathrm{D} 25$ & 6 & D32 & 4 & 1.05 & 203 & 16.1 \\
\hline 15 & & SRJ80S4 & D32 & 6 & D32 & 4 & 1. 34 & 234 & 20.8 \\
\hline
\end{tabular}

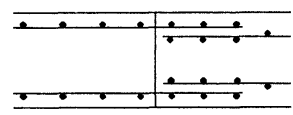

(a) 主筋構造

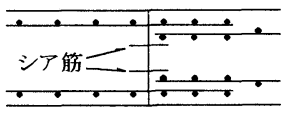

(b) シア筋構造
図-6 継手の配筋方法

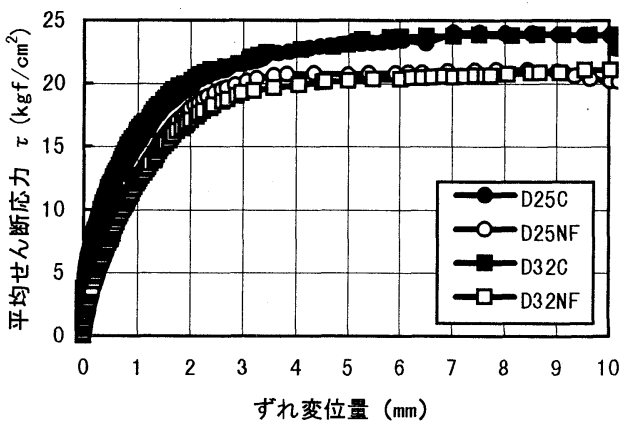

図-7ずれ変位履歴

これに対して，Bシリーズは，地中連続壁の本体 利用を進めることを目的として，せん断耐力を把握 するために実施したもので，せん断面が $74 \mathrm{~cm} \times 80 \mathrm{~cm}$ と大型で，かつ壁体間の仕切りに $9 \mathrm{~mm}$ 厚の鋼材を設 置することで平滑面とした.

配筋は，図-6に示すように，主筋のみでせん断力 を伝達する主筋構造と，せ九断補強筋にシア筋を配 置したシア筋構造とした。なお，使用した試験体は， 表-5に示すように，主筋構造が 7 体で，シア筋構造 が 8 体の合計15体とした。ここで，主筋構造は，主 筋に使用した鉄筋の径と本数を主な試験体諸元とし た。一方，シア筋構造は，主筋の径，シア筋の本数， およびシア筋の長さを主な試験体諸元とした. No.

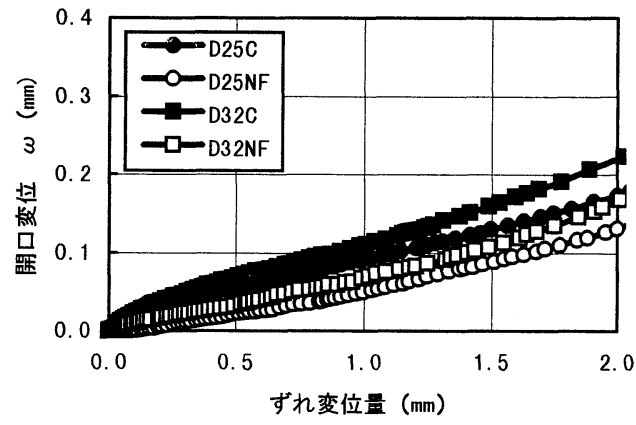

図-8 開口変位とずれ変位の関係

$8,9,10$ 試験体は，シア筋の長さを $15 \mathrm{~cm}, 25 \mathrm{~cm}, 40 \mathrm{~cm}$ と変え, シア筋の有効長さを把握するために行った ものである．実験の結果および実施工におけるせん 断補強筋の取り付け長さを考慮し, 他の試験体では シア筋の長さを $25 \mathrm{~cm}$ とした。 なお，使用した鉄筋の うちD32はAシリーズと同一のものであるが，D25 には降伏強度 $3762 \mathrm{kgf} / \mathrm{cm}^{2}$ ，またD 16 には降伏強度 $3491 \mathrm{kgf} / \mathrm{cm}^{2}$ の SD295 を使用した。

\section{4. せん断伝達機構}

\section{（1）せん断面における変位}

図一7は，せん断面におけるずれ変位履歴を示した ものである．接合面の摩擦を除去したD25NFおよび D32NF試験体は，載荷開始とともにずれ変位が生じ， 同様な履歴性状を示している．これら試験体は，鉄 筋の径を異にするが，D25およびD32をほぼ同一の 鉄筋比になるように配置したものである.

一方，後打ち部分を先打ち部分に直接打設した試 験体は，載荷開始時において接合面が接着している 


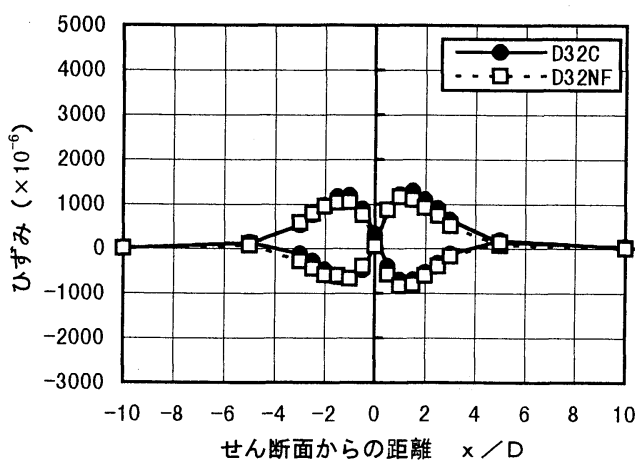

(a) $\delta=0.5 \mathrm{~mm}$

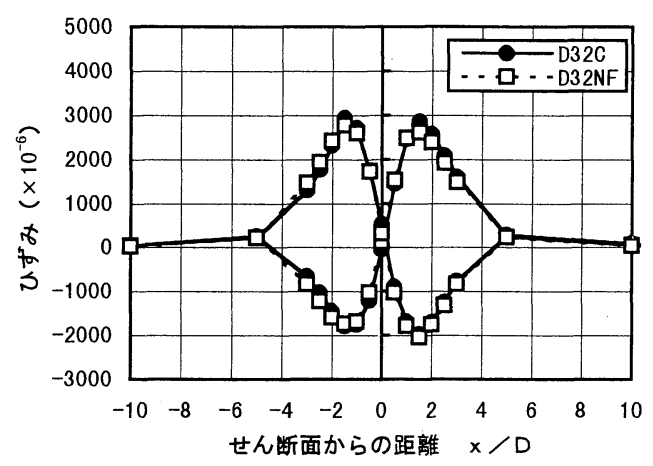

(c) $\delta=1.5 \mathrm{~mm}$

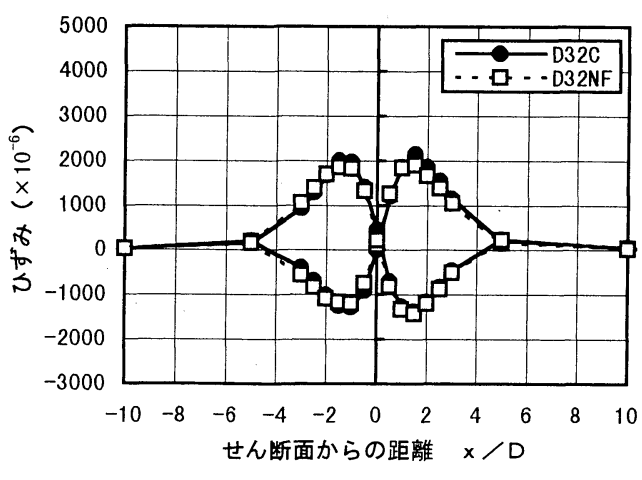

(b) $\delta=1.0 \mathrm{~mm}$

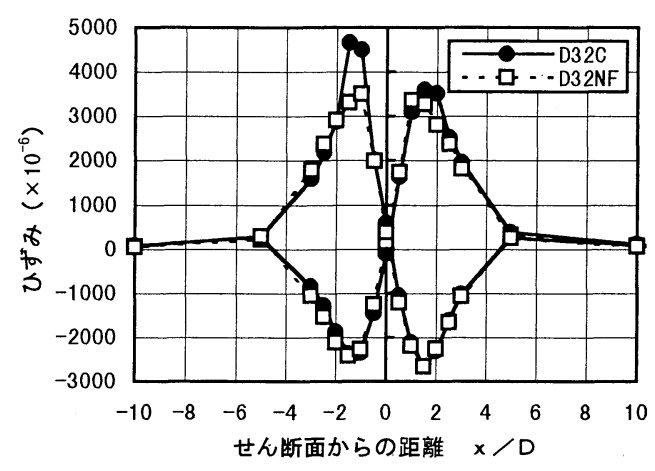

(d) $\delta=2.0 \mathrm{~mm}$

図-9 鉄筋のひずみ分布

ため, あるせん断応力に達して初めてずれ変位が生

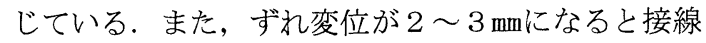
剛性は相当に低下するが，その後においてもせん断 応力は漸増していくことが認められる.

図-8は，開口変位とずれ変位の関係を示したもの である．接触面での摩擦の有無，鉄筋径に関わらず 同様な挙動を示し, 両者の間には線形関係が認めら れる.また, 開口変位は, ずれ変位の $1 / 15 \sim 1 / 9$ に すぎず，ずれ変位に比べて小さなものである.

本実験は，このように開口変位に比べせん断面で のずれ変位が卓越する場合での鉄筋のダウエル作用 を対象としている。

図-9は，0.5mm, $1.0 \mathrm{~mm}, 1.5 \mathrm{~mm}, 2.0 \mathrm{~mm}$ のずれ変位 時における鉄筋ひずみ分布を, せん断面における摩 擦の有無の比較を含めて示したものである. 鉄筋ひ ずみは, せん断面から $5 \mathrm{D}$ 以内と極めて小さな領域 で大きな值を示している，また，せん断面から同一
の距離における測定值をみると, 若干引張側が大き いものの, 引張と圧縮と逆方向でほぼ同一のひずみ の絶対值となっている.これは, 鉄筋には軸引張力 が作用しているものの，鉄筋のダウエル作用として 曲げが支配的となっていることを意味する.

次に，せん断面における摩擦の有無について比較 すると, 同一のずれ変位であれば，両者ともほぼ同 一のひずみ值となり, またずれ変位とともに最大ひ ずみが増大していることが認められる。

例えば，(b)に示す $1.0 \mathrm{~mm}$ のずれ変位量でみると， 引張側で $2000 \times 10^{-6}$, 圧縮側で $1500 \times 10^{-6}$ と鉄筋の 降伏あるいはそれに近いひずみとなっている，また， (d)に示す $2.0 \mathrm{~mm}$ のずれ変位量でみると, 圧縮, 引張 ともに $3000 \times 10^{-6} に$ 近いか, それを超える大ひずみ となっている.この大ひずみを示す鉄筋断面位置は, せん断面から $1.5 \mathrm{D}$ の位置に存在していることが認 められる。 


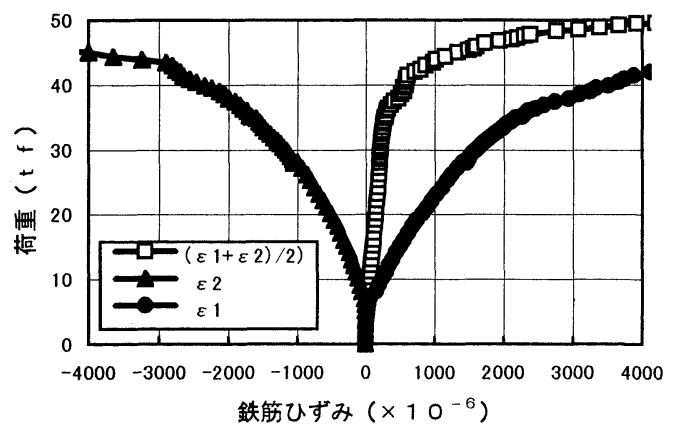

(a) $\mathrm{D} 25 \mathrm{C}$

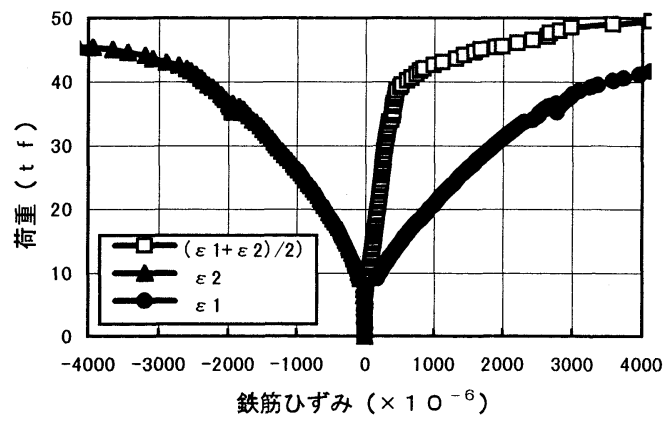

(c) $\mathrm{D} 32 \mathrm{C}$

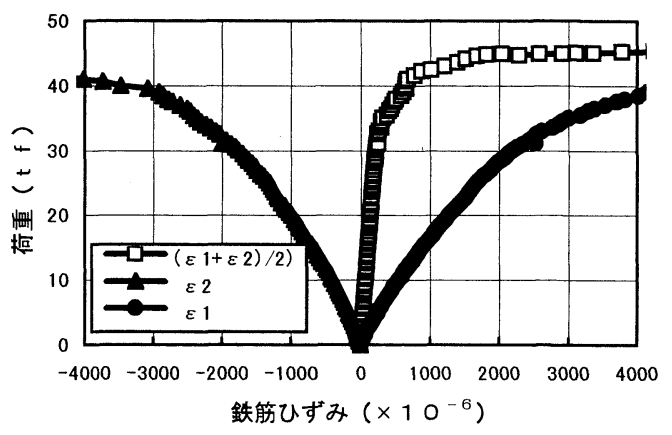

(b) $\mathrm{D} 25 \mathrm{NF}$

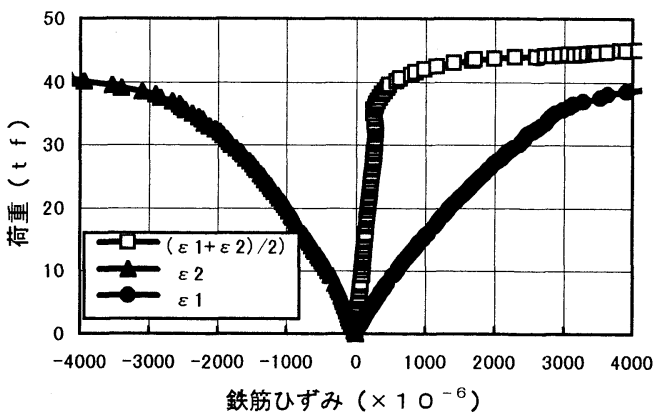

(d) $\mathrm{D} 32 \mathrm{NF}$

図-10 鉄筋のひずみ履歴
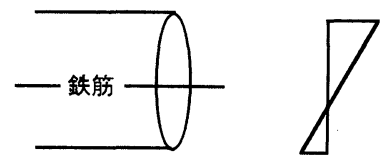

(a) 弾性状態

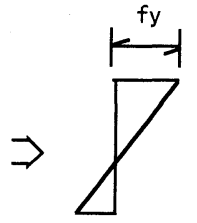

(b) 縁降伏

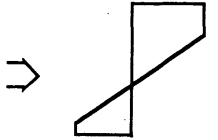

(c) 塑性進行

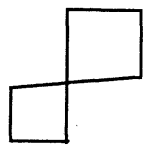

(d) $\tau$ sy

図-11 鉄筋断面内の応力状態

図-10は，せん断面から1.5D位置における溝切り 加工部での測定ひずみ $\varepsilon_{1} ， \varepsilon_{2}$ と，平均ひずみの履 歴を示したものである. せん断面の摩擦を除去した 試験体は，せん断応力の作用とともにひずみの值が 線形的に増加している．また，せん断面での摩擦を 有する試験体では，ずれ変位が生じるあるせん断応 力に達した後，ひずみの值が増加している。ここで, 軸ひずみに相当する平均ひずみに着目すると，引張 側の值となっているものの，E ${ }_{1}$ が $2000 \times 10^{-6}$ と降 伏ひずみ相当に達しても，1/10以下と小さな值とな つている. しかし， $\varepsilon_{1}$ の值がさらに増加し， 3000 $\times 10^{-6}$ を超える付近から平均ひずみが急激に值を大
きくすることが認められる．このような実験結果に 基づくと，せん断面から $1.5 \mathrm{D}$ 離れた支配断面での 鉄筋応力状態は, 図-11に示すように推移すると推 定される，せん断面におけるずれ変位が小さい状態 においては全断面弾性状態であるが，作用せん断力 の増加とともに引張縁で降伏が開始し, 鉄筋断面内 において塑性領域が進行する，さらに，軸ひずみが 降伏ひずみに達する $\tau_{\mathrm{sy}}$ （以下降伏せん断強度と称 す）に至る.

この降伏せん断強度時には，鉄筋の図心近傍にお いて応力勾配が大きく, 全塑性応力状態に近似でき るものと推定される. 

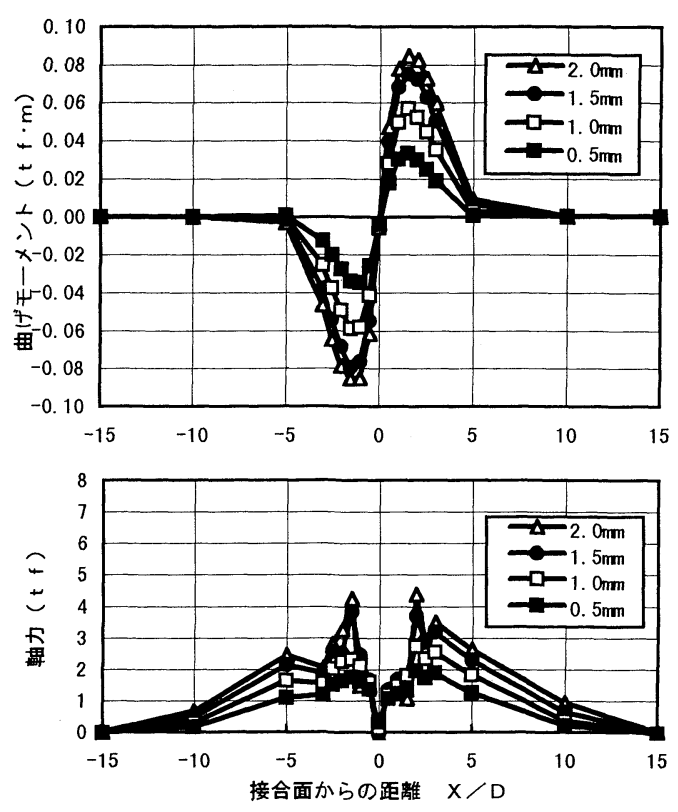

(a) $\mathrm{D} 25 \mathrm{C}$
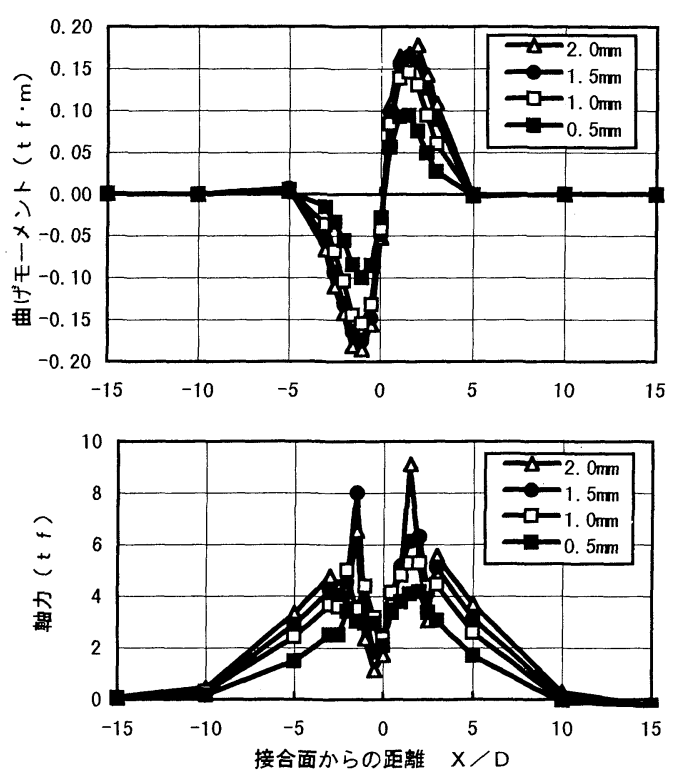

(c) D 32 C
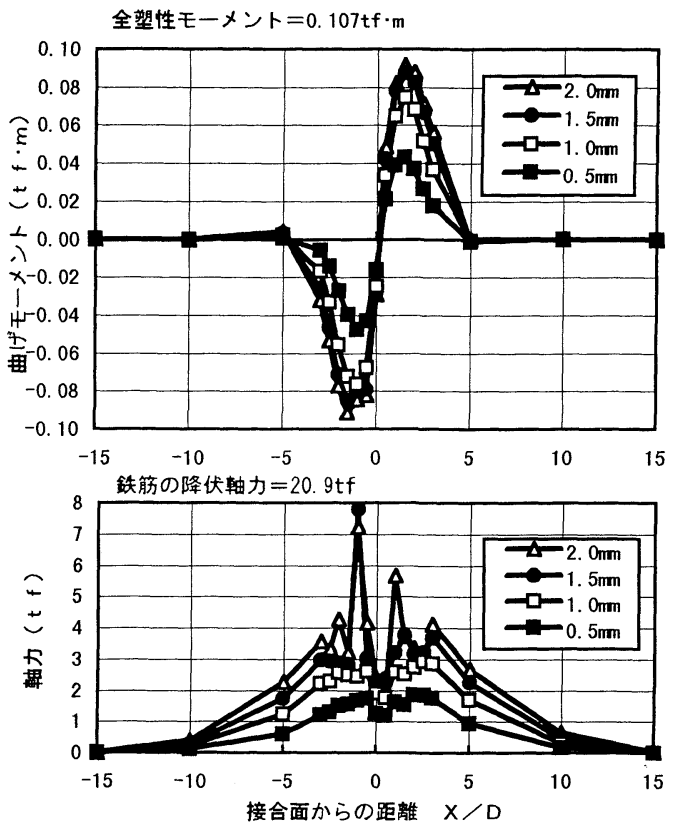

(b) D $25 \mathrm{NF}$
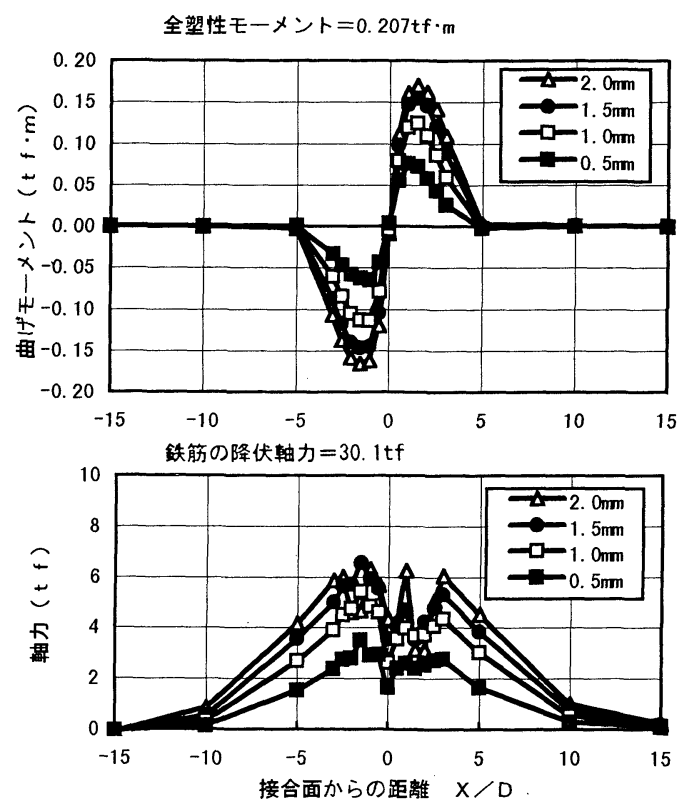

(d) D $32 N F$

図-12 鉄筋のモーメントおよび軸力分布

\section{（2）軸方向鉄筋の耐荷機構}

図-12は，鉄筋が負担している曲げモーメントM と軸力Nのせん断面からの距離に対する分布を示し たものである。これは，図-13に示すひずみ分布と 応力分布との関係, および測定ひずみから式 (1), (2)で算定したものである.

$$
\begin{aligned}
& M=\int_{-D / 2}^{D / 2} \sigma_{s}(y) \cdot y \cdot d A_{s} \\
& N=\int_{-D / 2}^{D / 2} \sigma_{s}(y) \cdot d A_{s}
\end{aligned}
$$




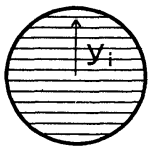

(a) 鉄筋断面

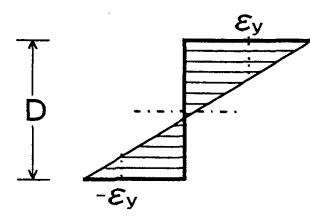

(b)ひずみ分布

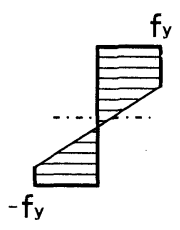

(c) 応力分布
図-13 鉄筋のひずみおよび応力分布
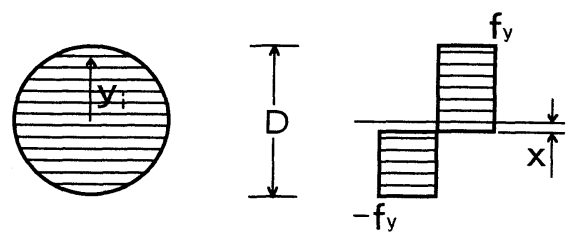

図-14 鉄筋の全塑性応力状態

鉄筋に作用している曲げモーメントは，せん断面 から 5 D以内に作用している．また，せん断面から $1.5 \mathrm{D}$ の位置で最大となり，この最大を示す支配断 面ではずれ量とともに曲げモーメントを大きくし， 鉄筋の全塑性モーメントに近づくようになる.この ような曲げモーメント分布は, せん断面における摩 擦の有無にかかわらず同様な傾向を示している.

これに対して，軸力は，せん断面から３Ｄ可間 において測定值に乱れが生じている。これは３D区 間での局部的な変形，付着の劣化によるものと思わ れる．また，せん断面から $5 \mathrm{D}$ 位置を越えても軸力 は生じているが，線形的に值を小さくしており，せ 几断面から $3 \mathrm{D}$ 位置と $15 \mathrm{D}$ 位置の間が鉄筋の定着領 域となっていることを示唆している，なお，せん断 面から $1.5 \mathrm{D}$ の位置に着目すると，軸力は，一軸の 降伏強度に対して $20 \%$ 程度，あるいはそれを下回る 值となっている.

鉄筋断面内における全塑性応力状態を図-14に示 す. また, この応力状態から, 曲げと軸力は式 ( 3 ), (4)で表すことができる.

$$
\begin{aligned}
& M=\int_{-D / 2}^{D / 2} f_{y} \cdot y \cdot d A \\
& N=\int_{-x}^{x} f_{y} \cdot d A
\end{aligned}
$$

全塑性状態における鉄筋の終局耐力 $M_{u}$ と $N_{u}$ の間 の相互作用図を示すと，図-15となる．曲げと軸力 が連成して作用したとしても， $\mathrm{N}_{\mathrm{u}} / \mathrm{N}$ 。が0.3以下で あれば, $M_{u} / M_{0}$ が0.92以上と, 軸引張力が小さい

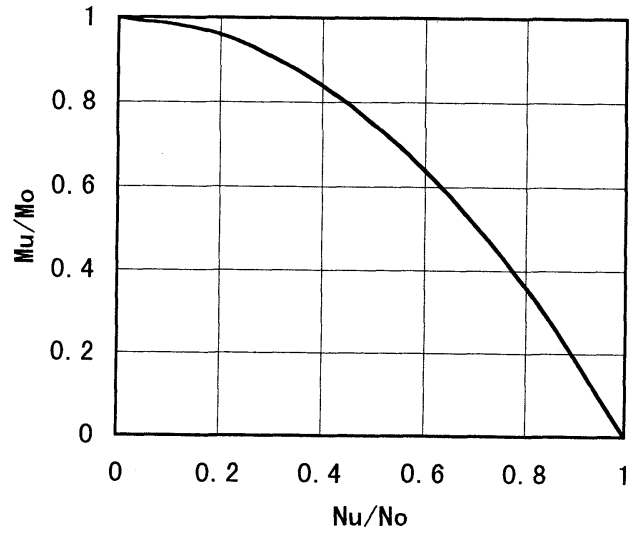

図-15 鉄筋の $M-N$ 相互作用図

領域では，曲げに支配されることがわかる．平滑な 面でのせん断伝達を考えると，軸力の分布から明ら かとされたように, 軸引張力が一軸の降伏強度に対 して $20 \%$ 程度，あるいはそれ以下と小さい。 そのた め, 耐力が決定されるせん断面から1.5D離れた位 置では, 軸引張力の影響が小さく, 全塑性モーメン トに近い曲げモーメントを負担しているものと推定 される.

このように，せん断面での開口変位が小さくずれ 変位が卓越するような平滑面における作用せん断力 は，せん断面を貫通する鉄筋の曲げにより，せん断 面から 5 D 以内と局部的な領域で抵抗されることが 確認された. この鉄筋に曲げが作用している領域は, 前川ら ${ }^{3)}$, Gambarovaら ${ }^{11)}$ が確認している鉄筋に曲 率の生じている領域とほぼ一致している.

\section{（3）降伏せん断強度}

せん断応力とずれ変位の関係は, 図-16に示すよ うに，下記の 3 領域に分けることができる.

(1) ほぼ一定の大きな剛性を有する領域

(2) 剛性が徐々に低下する領域

(3) 剛性が低下し変形の増大する領域

(1)の領域は，鉄筋のひずみが弾性状態で，ずれ変 位の小さい状態といえる。 (2)の領域は, $Y_{1}$ 点から引 張縁降伏が開始し，鉄筋断面内に塑性化が進む範囲 である、鉄筋の支配断面において全塑性状態に近似 されるY 2 点に達すると, 軸方向鉄筋に塑性ヒンジが 形成されることとなり,ずれ変位が増大することと なる. なお, 開口変位もずれ変位とともに増し, こ れによりせん断面への軸方向鉄筋による圧縮力が増 加し, せん断面の摩擦でせん断力の一部が負担され ることとなる．図-7のせん断面におけるずれ変位履 歴で示されたように，せん断面での摩擦を除去した 


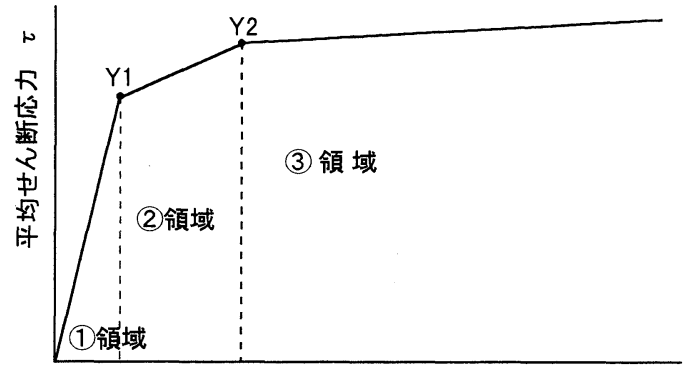

ずれ变位量 $\delta$

図-16 せん断応力〜ずれ変位概要図

試験体ではずれ変位を大きくしても作用せん断応力 が頭打ちとなり，一方摩擦を有する試験体ではせん 断応力が漸増していくのは，摩擦に起因するこのせ ん断面でのせん断力の負担によるものと思われる.

降伏せん断強度は，このようなことから，塑性ヒ ンジが形成される $\mathrm{Y}_{2}$ 点に着目して算定していくこと とする.

降伏せん断強度時は，ずれ変位が進み，鉄筋が曲 げを受け大きな曲率を示すため，鉄筋近傍のコンク リートは鉄筋の変形に追随できず，圧砕を生じてい るものと推定される．ただし，図-12の軸力分布に 示されたように, せん断面から $3 \mathrm{D}$ 以上離れた領域 で鉄筋の定着が確実になされているように，周囲の コンクリートは健全な状態と考えられる．コンクリ 一トの破壊は局部的で, 周囲を健全なコンクリート で拘束された支圧状態となるため，見かけ上圧縮強 度が大きくなる。そこで，降伏せん断強度時におい て，鉄筋の作用荷重は図-17に示すように仮定でき る.

鉄筋に作用するモーメントMsは，式（５)で表さ れる。

$$
\begin{aligned}
M s=\frac{-m \cdot f^{\prime}{ }_{c} \cdot \pi \cdot D\left(x-\frac{2 Q}{m \cdot f^{\prime}{ }^{\prime} \cdot \pi \cdot D}\right)^{2}}{4} \\
+\frac{Q^{2}}{m \cdot f^{\prime}{ }^{\prime} \cdot \pi \cdot D}
\end{aligned}
$$

ここに,

$\mathrm{Q}$; 作用せ九断力

$\mathrm{f}^{\prime}{ }_{\mathrm{c}}$; コンクリートの圧縮強度

$\mathrm{D} ;$ 鉄筋径

$\mathrm{x}$; 女九断面からの距離 $(0 \leqq \mathrm{x} \leqq \mathrm{x} 。)$

$\mathrm{m}$; コン夘ートの圧縮強度増加係数

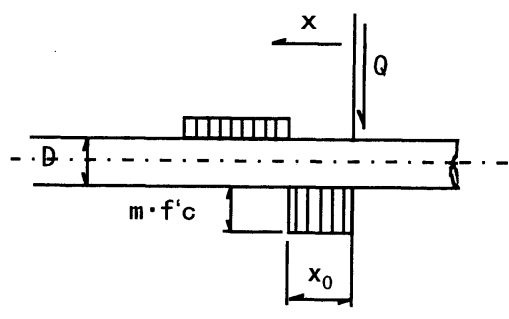

図-17 鉄笳への作用荷重状態

また，モーメントの最大值 $M_{\operatorname{smax}}$ は，式(6) とな る.

$$
M_{s \max }=\frac{Q^{2}}{m \cdot f^{\prime}{ }^{\prime} \cdot \pi \cdot D}
$$

鉄筋は，支配断面において全塑性状態で抵抗する と考えられる.この全塑性モーメント $\mathrm{M}_{\mathrm{s}}$ 梳式 (7) で表される.

$$
M_{s r}=\int f_{y} \cdot y d A=\frac{D^{3} \cdot f_{y}}{6}
$$

ここに,

$\mathrm{f}_{\mathrm{y}}$ : 鉄筋の降伏強度

また， $M_{s \operatorname{sax}}$ と $M_{s r}$ は等しいことから，式(8)が 得られる。

$$
\frac{Q^{2}}{m \cdot f^{\prime}{ }_{c} \cdot \pi \cdot D}=\frac{D^{3} \cdot f_{y}}{6}
$$

降伏せん断強度 s $_{s}$ は，これらより式 $(9)$ で表さ れる。

$$
\begin{array}{r}
\frac{\tau_{s y}}{\sqrt{f^{\prime}{ }_{c}}}=\alpha \cdot p \cdot \sqrt{f_{y}} \\
\text { ここに, } \alpha ; \text { 定数 } \\
\mathrm{p} ; \text { 鉄筋比 }
\end{array}
$$

図-18は，大型一面せん断試験結果を， $\tau_{\mathrm{sy}} / \sqrt{f^{\prime} \mathrm{c}}$ 縦軸に, $\mathrm{p} \sqrt{\mathrm{f}_{\mathrm{y}}}$ を横軸にプロットしたものである．実 験結果は図に示すように良い線形関係を示している. そこで，実験値との関係から， $\alpha=1.74$ として，降 伏せん断強度 $\tau_{\mathrm{s} \mathrm{y}}$ を，式(10)で表すこととする．

$$
\frac{\tau_{s y}}{\sqrt{f^{\prime} c}}=1.74 \cdot p \cdot \sqrt{f_{y}}
$$




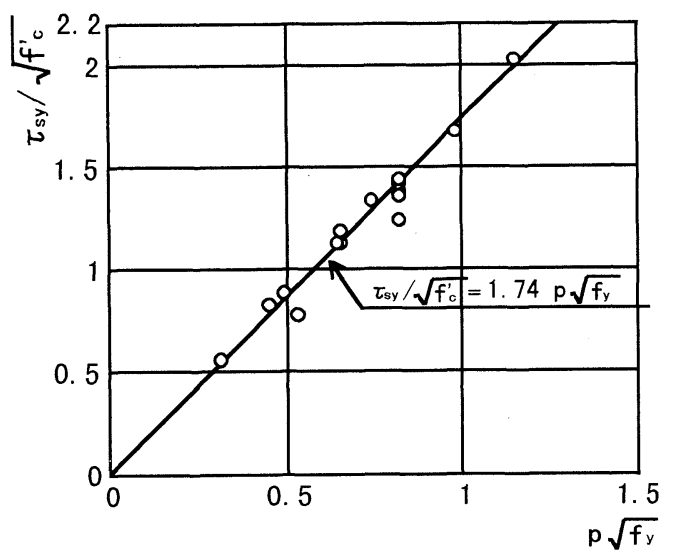

図-18 $\tau_{s y} / \sqrt{f^{\prime}} \sim p \sqrt{f_{y}}$ 関係

式 (10) は実験值との変動係数が5. $5 \%$ と, 実験值 との良い一致が認められた.さらに，既往に実施さ れた実験結果と合わせて示すと, 図一19となる。計 算值と実測值の良い一致が認められる。これらの実 験結果は，接合面を貫通する鉄筋比で1. $88 \%$ までを 実験範囲としており, 一般の構造物としては上限值 といえる.また，計算值との比較においてコンクリ 一ト強度は, $200 \mathrm{kgf} / \mathrm{cm}^{2}$ (19 MP a) 〜 $488 \mathrm{kgf} / \mathrm{cm}^{2}$ (48 MP a) と広範囲に取り扱っている. 平滑な接合 面における鉄筋のダウエル作用は，このように，鉄 筋の曲げ抵抗に着目した耐力評価法で, 精度良く推 定できることが確認された。

\section{5. 結論}

平滑面でのせん断伝達として, 開口変位に比べず れ変位が卓越する場合における鉄筋のダウエル作用 のメカニズム把握を研究目的に実験的検討を行った. その結果以下に示古結論を得た.

（1）平滑な接合面と直交した鉄筋は，せん断力が 作用し, 接合面のずれ変位が増加すると, せん断面 から 5 D区間で断面の曲率が増加する曲げ変形を示 していく，また，本実験の範囲においては，曲率の 最も大きくなる支配断面は, せん断面から1.5Dの 位置であった。

（2）鉄筋には曲げと軸引張が連成して作用してい る.しかし, 軸引張力の影響は降伏強度の $20 \%$ 程度, あるいはそれ以下と小さい. 接合面でのずれ変位量 が $2 \mathrm{~mm}$ を超えるようになると, 支配断面での塑性化 が進み, 抵抗モーメントは全塑性モーメントに近似

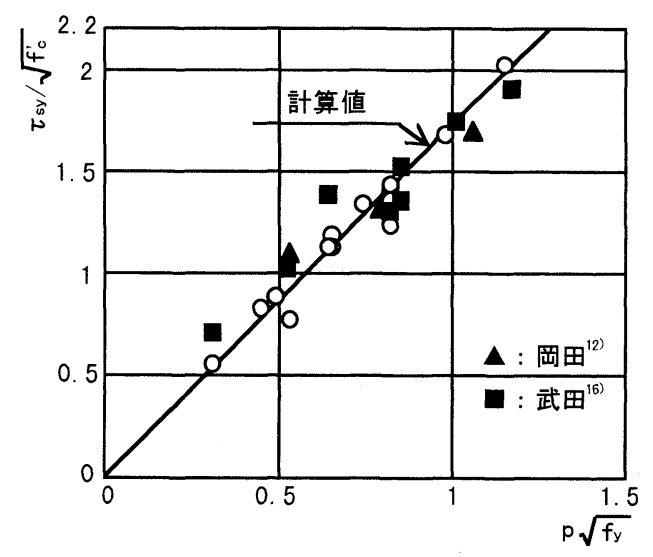

図-19 $\tau_{\mathrm{sy}} / \sqrt{\mathrm{f}_{\mathrm{c}}^{\prime}} \sim \mathrm{p} \sqrt{\mathrm{fy}}$ 関係

できるようになってくる.このように，鉄筋の抵抗 機構として，曲げ抵抗が支配的であることが確認さ れた。

（3）荷重とずれ変位の関係は，(1)初期のほぼ一定 の大きな剛性を有する領域，(2)剛性が徐々に低下す る領域, (3)剛性が低下し変形の増大する領域, の3 領域に分けられる。このうち, 耐力が決定される降 伏せん断強度は, (2)から(3)八移行する点に対応して いると考えられる。この際，鉄笳はせん断面から 1. 5D位置で全塑性応力状態に近づいていると考え ることができる。

（4）作用荷重と全塑性モーメントの関係から, 降 伏せん断強度の評価式として, 式(10)を提案した。

\section{参考文献}

1) 土木学会 : コンクリート標準示方書【平成 3 年版】 施工編.

2) 鈴木基行, 中村泰介, 堀内信, 尾坂芳夫 : 軸方向鉄筋ダ ウエル作用に及ぼす引張力の影響に関する実験的研究, 土木学会論文集, No. 426/V-14, pp. 159-166, 1991.

3) Maekawa, K.and Qureshi,J.: Embedded bar behavior in concrete under combined axial pullout and transverse displacement, Proceedings of the JSCE, No.532/V-30, pp.183-195,1996.

4) Maekawa, K and Qureshi, J .: Computational model for reinforcing bar embedded in concrete under combined axial pullout and transverse displace-ment, Proceedings of the JSCE, No.538/ V -31,pp.227-239,1996.

5) Paulay, T., Park, R. and Phillips, M. H. : Horizontal constraction joint in cast-in-place reinforcedconcrete, $A C I$, SP42-27,pp.599-616,1974.

6) Krefeld, W. J. and Thurston, C. W. : Contribution of longitudinal steel to shear resistance of reinforced concrete beam, ACI Journal, Vol.63, No.3, pp.325-344, 1966.3. 
7) Taylor, H. P. J. : The fundamental behavior of rein-forced concrete beams in bending and shear, $A C I$, SP42-3, pp.43-77,1974.

8) Houde,J. and Smiza, M. : Investigation of shear transfer across crack by aggregate interrock, Ecole Polytechnique, Genie Civil Report72-85, 1972.8.

9) Dulacska ,H.:Dowel action of reinforced crossing crack in concrete, ACI Journal ,Vol.69,No.12, pp.754-757, 1972.12

10) 山田一宇, 青柳征夫 : ひびわれ面におけるせん断伝達,

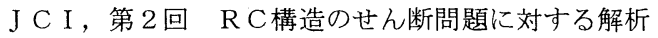
的研究に関するコロキウム,1983.10.

11) Dei Poli, S. „Di Prisco, M. and Gambarova, P. G. : Shearresponse, deformation, and subgrade stiffness of a dowel bar embedded in concrete, ACI Structural Journal, 89, No.6, pp.665-675, November-December, 1992.

12) 岡田武二, 武川芳広:SSS 工法に関する実験的研究 (そ の 6)，清水建設研究所報第 36 号,1982.10.

13) 入沢賢一, 武田寿一：鉛直継手による地中壁の一体化
に関する実験的研究（その 2)，大林組技術研究所報 No.26, 1983.

14) 山田一宇, 山村健, 香山康晴, 篠田佳男 : 地下連続壁 鈶直継手の構造耐力に関する研究（その 2)，前田建 設技術研究所報 Vol.26, 1985 .

15) 海野隆哉, 大植英亮 : 地下連続壁井筒の設計法と現場 水平載荷試験, 土木技術 36 巻 5 号, 1981.5.

16) 武田寿一, 入沢賢一, 大内一, 佐藤峰生 : 鉛直継手に よる地中壁の一体化に関する実験的研究（その 1 ）面外加力のせん断, 曲げせん断, 純曲げ実験一, 大林 組技術研究所報,No.21,1980.

17) 岡田武二：コンクリート接合面のせん断伝達に関する る研究, 土木学会論文集, No.502/ V -25, pp.73-82, 1994.11.

(1996. 7. 26受付)

\section{A STUDY ON THE SHEAR TRANSFER OF REBARS ON THE CONSTRUCTION JOINT WITH SMOOTHING SURFACE}

\section{Yoshio SHINODA, Kazunori KOHNO, Noriaki TANAKA and Takumi OHNO}

This paper describes the experimental investigation on the mechanism of the dowelaction of rebars for the construction joint with smoothing surface. This test wascarried out with push-off type shear specimen to investigate the detail of sheartransfer mechanism with the relatively larger size rebars, i.e. D 25 and D 32.As the result, it was revealed that the shear force, which occurs mainly due to rebarsbending, exists on te local area within the distance of 5 times of rebar diameterfrom the joint surface. In addition, shear yield capacity equation based on theplastic state is proposed, and its accuracy is demonstrated. 